\title{
Publisher Correction: Duplicate Publication of Articles in International Journal of Theoretical Physics, Volume 60; Issue 2
}

\section{Springer ${ }^{1}$}

Published online: 30 June 2021

(C) Springer Science+Business Media, LLC, part of Springer Nature 2021

Publisher Correction: International Journal of Theoretical Physics (2021) https://doi.org/10.1007/s10773-019-04067-x; https://doi.org/10.1007/s10773-020-04460-x

These articles were published twice due to an oversight during the processing of the new submission of the manuscripts.

https://link.springer.com/article/10.1007/s10773-019-04067-x

https://link.springer.com/article/10.1007/s10773-020-04460-x

The publisher wishes to apologize for this mistake.

Publisher's Note Springer Nature remains neutral with regard to jurisdictional claims in published maps and institutional affiliations.

The online version of the original articles can be found at https://doi.org/10.1007/s10773-019-04067-x; https://doi.org/10.1007/s10773-020-04460-x

\section{Springer}

